the bicycle-riding public. I had the pleasure of a conversation with four working men whom I met the other evening on a country road. Fach had a bicycle of a bad description, and I was not surprised to hear from them that their mounts were rough in the riding and galled them awfully. Still, the machines were very useful to them, for they enabled the men to come into Lincoln to their work from a village six miles away in forty minutes which used to take them an hour and a half to walk. I am, Sirs, yours faithfully,

WILLIAM O'NeIL, M.D., M.R.C.P. Lond,, \&c. Lincoln, June 2nd, 1896.

\section{" RATIONAL THERAPEUTICS AND COMMON REMEDIES."}

To the Editors of THE LANCET.

Sirs,-In the interesting and instructive paper published in THE LANCET of May 30th, under the above title, Dr. Samuel West asks for instances in which iodide of potassium has caused stoppage of the secretion of milk, and he also speaks of this drug as an efficient galactogogue. I must confess that I have always consiclered it to be quite the reverse; and in cases where I have thought it advisable to recommend a nursing mother to wean her infant I have been in the habit of prescribing from fifteen to twenty grains of iodide of potassium, to be repeated two or three times at short intervals, for the very purpose of stopping the flow of milk, and with very satisfactory and speedy results. In this treatment I am only following that recommended in the textbooks of Playfair and Galabin.

I am, Sirs, yours faithfully, June 1st, 1896.

R. Bruce Ferguson, M.A., M.D. Cantab., \&c.

\section{"THE CHURCH ANTI-VIVISECTION LEAGUE AND HOSPITAL SUNDAY." \\ To the Editors of THE LANCET.}

SIRS,-We have reason to be very grateful to you for the increased publicity you have given to the circular of our committee by inserting it in your widely read journal. That you should, however, think it needful to ask for proof of the alienation of people from the Church by the attitude of, at any rate, a portion of the clergy on the vivisection question is a curious proof of what different circles we Londoners can dwell in. Of the feeling of which you seem altogether ignorant daily proofs are thrust upon me. I have, of course, no right in a public journal to mention without their consent the names of others in a matter concerning their spiritual life, but I can at least speak for myself. I am by this cause prevented from attending my parish church, where I should otherwise have been a regular worshipper, and have to go elsewhere to a church where I know the clergy to be anti-vivisectionists. Nothing (unless it be the attitude of many clergy at the time of the Eastern war) has ever been so great a strain on my faith as their indifference to this terrible sin, and I always carefully avoid as far as possible coming into contact with vivisectionist clergy, whether by contributing to their funds or otherwise, and I know I am but a fair sample of thousands in this. It is true that these clergy are generally unaware of the motives of our actions because respect for their sacred office seals our lips, but the fact remains all the same. Hardly a day passes without my coming across persons, both Anglican and Roman, who tell me how their faith has been strained, and, alas! too often weakened or destroyed. With your permission $I$ will give a few typical instances out of the well-nigh countless examples which might be adduced. 1. A lady, very devoted to the services of a well-known Paddington church, told me recently she wanted to take a house in that neighbourhood in order to attend the church, but could not do so till she ascertained the views of the clergy about vivisection. 2. A regular and derout attendant at a wellknown Kilburn church told me she had been obliged to leave and go to a church where the type of services was repugnant to her because the vicar of the former was not an antivivisectionist. 3. A lady in this immediate neighbourhood brought me in the winter an appeal she had received from the vicar of a North Kensington parish, saying she could not contribute unless he were an anti-vivisectionist. Unfortunately, I could give her no information on this point, but a little later he preacbed against vivisection and she then at once sent him a cheque. 4. Another North Kensington lady told me she had, alas! altogether given up attending church through having come across vivisectionist clergy. 5. A gentleman who writes the mystic letters M.D. after his name told me he hailed the existence of our society because he thought it would strengthen the faith of many waverers, and he mentioned that another antivivisectionist physician of his acquaintance had become almost an Unitarian on account of what he imagined to be the tone of the Church on this question. With regard to the theological argument in your article, I must confess I altogether fail to see how the extracts from St. Thomas Aquinas and St. Augustine support vivisection. It is an insult to common sense to assume that the right to kill and the right to torture are the same thing. A member of our league, already known to the public as an author, is preparing a catena which, when published, will conclusively show the real tone of Christian theology on this point.

I am, Sirs, yours obediently,

A. L. WOODWARD,

Hon. Sec., Church Anti-vivisection League.

Lancaster-road, w., May 29th, 1896.

** We publish this letter with great pleasure: first, on account of the motto at the head of our correspondence column; and, secondly, because it is interesting to see the ideas that some pecple have as to what constitutes "proof." It is a little hard upon Ladies 1 and 2 to assume their alienation from the Church. The Church is not a building. As to Nos. 3 and 4 we would direct the writer's attention to the twenty-sixth of the Articles of Religion.-EiD. L.

\section{"THE USE OF GUATACUM IN THE TREAT- MENT OF CHRONIC GOUTY AFFECTIONS." \\ is To the Editors of THE LANCET.}

"SIRS, - In the report of my observations at the Royal Medical and Chirurgical Society on Sir Alfred Garrod's paper on the Use of Guaiacum in the Treatment of Gout reference is made to a local method of treating the acute manifestation of this affection which I have employed with success. With your permission I will give the formula in full. I take half an ounce of iodide of potassium, dissolve it in half a pint of rectified spirit-methylated spirit is used in hospital practice--add one ounce of soap liniment, and then half a drachm each of oil of cajeput and oil of cloves. A piece of lint is soaked in this mixture, wrapped round the affected part, covered with protective and kept in place by a bandage. It acts as a powerful counter-irritant, and the inflammation usually subsides in from twelve to twenty-four hours. In addition I not uncommonly give a drachm of colchicum wine with ten grains of iodide of potassium three times a day. These large doses of colchicum wine induce brisk purgation, sometimes accompanied by vomiting, but they speedily cut short the attack. This mode of treatment is especially useful in the case of robust, full-bodied men in active employment, to whom the loss of a day's work is a serious consideration. In sciatica, lumbago, and rheumatism affecting one joint the local application of a liniment containing half an ounce of salicylate of sodium, half a drachm of oil of cajeput, fifteen minims of oil of eucalyptus, and half an ounce of soap liniment in six ounces of rectified spirit affords prompt relief.

I am, Sirs, your obedient servant,

Welbeck-street, W., May 31st, $1896 . \quad$ WILLIAM MURRELL.

\section{"NERVE GRAFTING FOR INJURY." To the Editors of THE LANCET.}

SiRs,-My attention has just been drawn to your notice in THE LANCET of March 7th, 1896, of the case of nerve grafting for injury which I reported in the Medical News. As I believe $\bar{I}$ stated in that report, the man was discharged the service of the army because of this disability. After the report was published and about five months after operation I received a letter from him asking aid in securing a pension. In this communication he stated that there had been no improvement resulting from the operation. Interested as he was in obtaining a pension it is barely possible that had there been any improvement he would have concealed it, but from what I know of the man I believe he is honest in his statement. The time which had 